\title{
Bringing multiliteracies into process writing approach in ELT classroom: Implementation and reflection
}

\author{
Salim Nabhan* \\ English Language Education Department, \\ Universitas PGRI Adi Buana Surabaya, Indonesia \\ *Corresponding Author \\ Email: salimnabhan@unipasby.ac.id
}

\begin{abstract}
Designing new pedagogy in response to the advancement of technology that requires the integration of literacy has became the issue in ELT classroom. What is more, the conception of teaching English skills, including writing, is not merely limited to the language skills target but also how the learners become multiliterate in facing todays' world. This article puts forward the framework of multiliteracies that is integrated in process writing approach to bridge the gap between literacy education and writing pedagogy. This study aims at investigating the enactment of the incorporation of multiliteracies with process writing approach and to explore the learners' reflection toward the use of the framework in their writing practices. The data were taken from online surveys, the participants' reflection, observation, and focus group discussion in the end of the study. Researcher used qualitative analysis with embedded quantitative data. The proposed framework was delivered to pre-service teachers (PST) in English Writing subject at the English Language Education Department, Faculty of Teacher Training and Education, Universitas PGRI Adi Buana Surabaya, Indonesia. Step by step procedures in process writing approach were incorporated with multiliteracies along with some activities used in teaching writing. Findings indicated that implementing the framework in teaching writing provides PSTs with the opportunities to embrace the multiple modes of meaning making and digital technology in writing, produce texts, and present them in multimodal and creative ways. In addition, despite several challenges in its implementation, the activities helped to improve the writing skill, decrease the chance of plagiarism, and increase the authentic writing. Finally, PSTs were motivated to enhance their digital literacy used in writing practices. As a result, the study suggests that multiliteracies had a space in the teaching writing skill following the guided procedures in process writing approach.
\end{abstract}

Keywords: multiliteracies; multimodality; process writing approach

$\begin{array}{llll}\text { Received: } & \text { Revised: } & \text { Accepted: } & \text { Published: } \\ 21 \text { May 2019 } & \text { 22 July 2019 } & \text { 12 August 2019 } & \text { 31 August 2019 }\end{array}$

\section{INTRODUCTION}

Encountering todays' technological advancement, literacy skills bring significant existance in the teaching and learning process. What is more, the concept of literacy has been expanding from its traditional meaning; it is beyond merely the ability of reading and writing. Thus, in the 21 st century 
Nabhan, EduLite: Journal of English Education, Literature, and Culture

learning, learners need to have the opportunity to acquire literacy as many literacies or multiliteracies. Cimbricz and Rath (as cited in Greco, 2015, p.4) conceptualized multiliteracies as "the multiple dimensions of visual, aural, and media in multimodal texts, largely enabled by technology." This is to say, multimodality and technology have become the key elements in providing the learners to be mulitilerate. Therefore, incorporating them would enable the learners to be literate in multiple modes of meaning making using digital platforms.

In addition, learners of today as digital native need to develop their knowledge and experiences toward the new emerging technologies adapted to their learning activities. Likewise, the educators need to prapare their learners for the new literacy practices embedded in their teaching in the classroom. Several studies of multiliteracies have promoted positive outcomes (Sewell \& Denton, 2011; Walsh, 2010; Warner, Richardson, \& Lange, 2019; Cloonan, 2010; (Rajendram, 2015). However, to date, little work has been done on the integration of mulitiliteracies pegagogy into process writing approach in ELT setting. As a result, no comprehensible learning teaching model has been laid out to bring multiliteracies in teaching writing that would give benefits both the skill of language as well as the literacy of the learners. Therefore, the research reported in this paper provides the design of putting multiliteracies into the process writing approach in ELT classroom and explore the learners' reflection of the framework.

\section{Pedagogy of multiliteracies}

The growth of technology has led to the development of literacy that was no longer associated with the paper based texts, but it tended to be more multimodal. Thus, The New London Group (NLG) constructed the term of multiliteracies in 1996. Since the development of multiple modes became the focus, the multiliteracies was set as approach to teaching and learning involving six different modes of meaning making: linguistic, visual, audio, gestural, spasial, and multimodal (NLG, 1996; Cope \& Kalantzis, 2009). Furtermore, multiliteracies pedagogy is defined as "different kind of pedagogy, one in which language and other modes of meaning are dynamic representational resources, constantly being remade by their users as they work to achieve their various cultural purpose" (NLG, 1996, p. 64). In general, implementing the pedagogy of multiliteracies originally necessitates four major components of situated practice, overt instruction, critical framing, and transformed practice (NLG, 1996), and it has been reframed into knowledge processes of experiencing, conceptualizing, analysing, and applying (Cope \& Kalantzis, 2009).

There have been several studies regarding the potentials of the implementation of multiliteracies pedagogy for teaching English language. A study conducted by Ganapathy (2016) indicated that learning English language using multiliteracies pedagogy with multimodal approach promotes students' independent learning, motivation, and learning techniques. Also, Smith (2014) has demonstrated that multimodal literacy could be incorporated in English language classroom by utilizing technology, and it brings positive outcomes. Moreover, Rajendram (2015) has concluded that multiliteracies pedagogy has been proven to be substantial in teaching English since it 
provides the students with multiple modes of communication offered by technology.

Despite these benefits, integrating multimodality brings several challenges. Sewell and Denton (2011) argued that bringing classroom to be more multimodal incorporating technology requires the teachers to learn the software, train the programs to the students, and modify the teaching style. Additionally, teachers faced complexity in deploying multimodal resources of texbooks to support the English language teaching in the classrooms in a away of creating the meaning (Ajayi, 2012). Despite the fact that the use of multiliteracies pedagogy has increased in English classroom activities, the practice of appropriate multiliteracies assesment tool still lacks (Rajendram, 2015).

\section{Approaches to teaching writing}

There have been numerous approaches to the teaching of writing in English language classroom as well as the arguments regarding their distinctive features and effectiveness (Nordin \& Mohammad, 2006). Regardless the debate on the option of the best approach, the use of those approaches is contingent on the level of students, type of texts, and other factors (Hasan \& Akhand, 2010). However, among those approaches, there are three major approaches that are dominated in teaching writing: product, genre, and process.

A product approach is referred as a traditonal approach in which students are directed to imitate the model of the texts and then produce a new piece of writing (Gabrielatos, as cited in Hasan \& Akhand, 2010). Additionally, this approach focuses on the text as the final outcomes and on the language elements of grammar and mechanics (Tangkiengsirisin, 2006). This is to say, writing is seen as the skill of understanding and practising the structure of language, and the result of writing is reflected from the given pattern. In implementing the approach, Steele (as cited in Hasan \& Akhand, 2010) explained the four steps as the model of the approach: the texts model identification, controlled practice of the features, organization of idea, and production. Not much different from the product approach, the genre approach is considered as the extension of the product approach in which the approach draws attention to the social context in its production (Badger \& White, as cited in Nordin \& Mohammad, 2006).

In contrast, process approach emphasizes the process itself in which students branstorm and develop the ideas, and thus, the focus of the approach is on the writer, rather than the text (Tangkiengsirisin, 2006). Correspondingly, this approach tends to involve a range of varied classroom activities that are collaborative, and it promotes a creative process of writing. Notwithstanding that some authors give different stages in the process writing, the basic patterns shows similarities. Coffin et al. (2003) suggested the stages of process writing covering prewriting to generate the ideas, planning, drafting, reflection, peer/tutor review, revision, and editing and proofreading. While Harmer (2004) and Johnson (as cited in Nabhan, 2016) have almost the same activities of process writing in the initial stages, Johnson gives spesific attention to publishing of the writing in the final stage.

Further, those three approaches could be seen as complementing, rather than opposing each other. However, in English language classroom, several 
Nabhan, EduLite: Journal of English Education, Literature, and Culture

studies are dominated by the positive outcomes of the students' writing skill toward the enactment of the process writing instead of product or genre approach. Study by Alodwan and Ibnian (2014) indicated that process writing approach is succesful to increase the university students' essay writing in EFL Classroom. Comparably, Nabhan (2016) concluded that the approach is proven to be effective to improve students' writing ability as it involves several engaging and creative activities.

\section{Multiliteracies and process approach framework}

The framework was designed to expand the teaching writing in English language classroom by integrating the process writing approach and multilitercies pedagogy. The model of stages in process writing approach is formulated from many sources as proposed by Coffin et al. (2003), Harmer (2004), and Johnson (as cited in Nabhan, 2016). These models are taken as complementary to each other. Additionally, the concept of multiliteracies is adapted from New London Group (1996), and it is developed by Cope \& Kalantzis (2009). Table 1 below shows the stages of process approach and multiliteracies along with the suggested activities.

Table 1. Stages and possible activities for multiliteracies and process approach framework

\begin{tabular}{|c|c|c|c|}
\hline No & $\begin{array}{l}\text { Stages of Process } \\
\text { Writing Approach }\end{array}$ & Possible activities & $\begin{array}{l}\text { Predominant modes } \\
\text { (mltimodal and } \\
\text { digital) }\end{array}$ \\
\hline 1 & $\begin{array}{l}\text { Pre writing. } \\
\text { The aim of this step is } \\
\text { to generate ideas, } \\
\text { collect infromation, and } \\
\text { organize thought that } \\
\text { includes brainstorming } \\
\text { and free writing }\end{array}$ & $\begin{array}{l}\text { Presenting the materials using } \\
\text { LCD Projector } \\
\text { Sharing the materials using } \\
\text { Google Classroom } \\
\text { Brainstorming using pictures } \\
\text { and videos about the given topics } \\
\text { such as bullying and pollution }\end{array}$ & 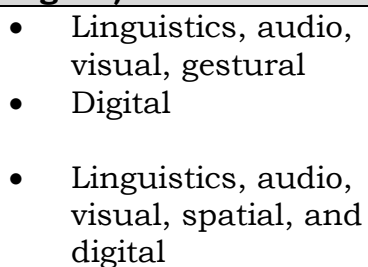 \\
\hline 2 & $\begin{array}{l}\text { Planning and } \\
\text { Organizing. } \\
\text { In this step, students } \\
\text { manage and focus the } \\
\text { ideas into outline using } \\
\text { mind mapping, } \\
\text { clustering, and listing }\end{array}$ & $\begin{array}{l}\text { Making mind map using Mind } \\
\text { Map online application } \\
\text { https://bubbl.us in group work } \\
\text { activities } \\
\text { - Sharing ideas throuh Whatsapp } \\
\text { Web and presenting using LCD } \\
\text { Projector } \\
\text { - Writing outline online using } \\
\text { Google Docs. } \\
\text { Displaying the mind map, } \\
\text { clustering, or listing in the } \\
\text { classroom } \\
\text { Reviewing the thesis statement } \\
\text { and outline online using Google } \\
\text { Docs. }\end{array}$ & $\begin{array}{ll}- & \begin{array}{l}\text { Visual, spatial, } \\
\text { digital }\end{array} \\
\text { - } & \text { Linguistics, visual, } \\
\text { spatial, digital } \\
\text { - } & \text { Linguistics, digital } \\
\text { - } & \begin{array}{l}\text { Linguistics, visual, } \\
\text { spatial }\end{array} \\
\text { - } & \text { Linguistics, digital }\end{array}$ \\
\hline 3 & $\begin{array}{l}\text { Drafting. } \\
\text { This step is aimed at } \\
\text { writing the initial draft } \\
\text { of the text that } \\
\text { emphazises on the } \\
\text { organization and ideas } \\
\text { development. }\end{array}$ & $\begin{array}{l}\text { Writing the first draft } \\
\text { (introduction, body paragraph, } \\
\text { concluding with transition } \\
\text { signals, good sentence structure, } \\
\text { and academic vocabulary) using } \\
\text { typed-writing in the students' } \\
\text { laptop/device }\end{array}$ & - $\quad$ Lingustics, digital \\
\hline 4 & $\begin{array}{l}\text { Reflection. } \\
\text { This step allows }\end{array}$ & $\begin{array}{l}\text { Letting the piece of writing save } \\
\text { in the students' device }\end{array}$ & - $\quad$ Digital \\
\hline
\end{tabular}




\begin{tabular}{|c|c|c|c|}
\hline & $\begin{array}{l}\text { students to let their } \\
\text { work of writing sit for } \\
\text { the time being and to } \\
\text { look at it again with } \\
\text { fresh mind. }\end{array}$ & & \\
\hline 5 & $\begin{array}{l}\text { Peer/Tutor Review. } \\
\text { This kind of step has a } \\
\text { purpose to give } \\
\text { comment toward the } \\
\text { piece of writing that is } \\
\text { under development. } \\
\text { This can be done by } \\
\text { tutor or by peers using } \\
\text { the guidelines provided } \\
\text { by the teacher. }\end{array}$ & $\begin{array}{l}\text { Submitting and reviewing the } \\
\text { draft online using Google Docs } \\
\text { (checking the format, content, } \\
\text { organization, grammar, } \\
\text { punctuation, capitalization, } \\
\text { spelling, and sentence structure) } \\
\text { Getting feedback online. }\end{array}$ & - $\quad$ Linguistics, digital \\
\hline 6 & $\begin{array}{l}\text { Revision. } \\
\text { In this step, students } \\
\text { further develop and } \\
\text { clarify the ideas and } \\
\text { the structure of the } \\
\text { text. }\end{array}$ & $\begin{array}{l}\text { - } \quad \text { Revision on screen texts. } \\
\text { Submitting the assignment } \\
\text { online }\end{array}$ & - $\quad$ Linguistics, digital \\
\hline 7 & $\begin{array}{l}\text { Editing and } \\
\text { Proofreading } \\
\text { This stage allows the } \\
\text { students to polish the } \\
\text { writing in terms of the } \\
\text { mechanic of writing } \\
\text { such as format and } \\
\text { language structure. }\end{array}$ & $\begin{array}{l}\text { - Writing a new copy with the final } \\
\text { revision and edit using typed } \\
\text { writing } \\
\text { Check Plagiarism using } \\
\text { Plagiarism Checker online } \\
\text { application } \\
\text { https://smallseotools.com/ } \\
\text { Proofreading using } \\
\text { https://smallseotools.com/ }\end{array}$ & $\begin{array}{ll}\text { - } & \text { Linguistics, digital } \\
\text { - } & \text { Digital } \\
\text { - } & \text { Digital }\end{array}$ \\
\hline 8 & $\begin{array}{l}\text { Publishing. } \\
\text { The aim of this final } \\
\text { step is to present and } \\
\text { publish the final work } \\
\text { of the students. }\end{array}$ & $\begin{array}{l}\text { - Creating, designing the brochure } \\
\text { using Adobe photoshop or other } \\
\text { application and presenting the } \\
\text { printed brochure } \\
\text { Creating the multimedia } \\
\text { presentation using movie maker } \\
\text { or other software, or upload in } \\
\text { the students' webblog. }\end{array}$ & $\begin{array}{ll}\text { - } & \text { Linguistics, visual, } \\
\text { spatial, digital } \\
\text { - } & \begin{array}{l}\text { Linguistics, audio, } \\
\text { visual, digital }\end{array}\end{array}$ \\
\hline
\end{tabular}

\section{METHOD \\ Study design}

A descriptive case study using qualitative analysis with embedded quantitative data was undertaken to assess the enactment of the integration of multiliteracis and process writing approach in ELT setting. The study was conducted in undergraduate English Writing subject (16-weeks, 3-credits) at Universitas PGRI Adi Buana Surabaya, Indonesia. The class was distinctive since it was designed to implement multiliteracies pedagogy. All activities and assignment were set to be multimodal and digital.

\section{Study participants}

The proposed framework was delivered to PSTs in Essay Writing subject, semester 3 at the English Language Education Department, Faculty of Teacher Training and Education, Universitas PGRI Adi Buana Surabaya. There were 28 PSTs in the class.PSTs were expected to be the English teachers after graduation. The participants were selected based on cluster sampling. PSTs had got Paragraph Writing Subject in the previous semester, thus the focus of 
Nabhan, EduLite: Journal of English Education, Literature, and Culture

the subject is essay writing. The participants of the study followed the steps of writing process approach as suggested in the framework and reflected their experiences.

\section{Implementation of multiliteracies and the process writing approach}

The students were taught writing using following procedures:

- Presenting the framework: the lecturer of the course (that is the researcher) introduced the aims of the courses and the framework to PSTs. The course was designed to integrate multiliteracies, including digital literacy, that was integrated in the writing process approach.

- Framework: Multiliteracies and Process Approach. In this steps, PSTs followed some activities based on the stages in process writing. It included pre writing, planning and organizing, drafting, reflection, peer/tutor review, revision, editing and proofreading, and publishing. This stages involved some multiple modes of meaning making such as linguistics, audio, visual, spatial, gestural. In addition, Literacy skill that were taught in every single stages was digital literacy. There were some softwares or online applications that were utilized in the classroom including Google classroom (https://classroom.google.com)for sharing the materials, Google docs for submitting the assigment, editing, and reviewing, Bubble website (https://bubbl.us)forcreatting mind map online, Whatsapp Web for sharing and presenting the ideas, Smallseotools website (https://smallseotools.com/) for checking plagiarism and proofreading. Finally, PSTs created posters and multimedia presentation and published them online.

- Reflections: PSTs were asked to write reflective diaries regarding the framework in the end of each stages.

\section{Data collection}

Two types of the data were utilized: quantitative and qualitative.The quantitative data were taken from online surveys given to PSTs in the classroom at the end of the study. Survey was conducted to investigate PSTs' perceptions toward the implementation of the suggested framework. There were twenty eight PSTs who submitted the survey. The researcher than imputted using statistical analysis software package SPSS 16.0 in terms of frequency (the number and percentage). Survey was adapted from Likert Scale consisting of five options of agreement level (Vagias, 2006). For reflection of the process writing and multiliteracies, the qualitative data were taken from the participants' reflection that were given in the end of the activities. In addition, to support the main data and get deeper understanding, researcher conducted focus group discussion and classroom observation.Focus group discussion was done with five PSTs that were taken randomly. Focus group discussion we conducted after finishing all the stages in the framework. A semi structured interview questionnaire was used. The main questions were as follows:

- What do you think about literacy?

- Do you see any connection between learning writing skills and multiliteracies, including digital literacies and the use of multiple modes in teaching learning? 
- Do multiliteracies and digital literacy support and improve your writing skills? e.g. the use of online application, in what ways?

- Do you get other benefits from the activities? please mention and elaborate.

- Do you find any difficulty in learning writing involving multiliteracies and digital literacy?

\section{Ethical consideration}

Prior to conducting the study, PSTs as the subjects of the study were given an explanation regarding the purpose, the benefits, methods, and steps of the research. They were also given written consents to signify the participants are supplied with enough information, understand the study, and agree to join the research (Mackey \& Gass, 2005). Besides, the data taken from students group discussion were transcribed and stored well.

\section{Data analysis}

In this study, the data were quantitative and qualitative. The quantitative data taken from PSTs' surveys were analysed using descriptive, and they were displayed in the form of frequency (percentage and the numbers). The researcher utilized statistical analysis software package SPSS 16.0. Regarding qualitative derived from reflective diaries, PSTs' focus group discussion, and observation, researcher developed the codes and categorised them. As a result, the themes were then identifed and emerged based on the research questions of the study. The emerged themes are understanding in learning writing, writing skill improvement, efficacy, digital literacy improvement, value of digital writing, benefits for future life, awareness of plagiarism, and the challenges. To validate the accurary of the findings, researcher employed the strategy of data triangualtion and member checking (Mackey, 2005).

\section{RESULTS AND DISCUSSION \\ Result \\ Surveys}

Table 2. PSTs' perceptions of experiencing multiliteracies and process writing approach framework

\begin{tabular}{|c|c|c|c|c|c|}
\hline \multirow[t]{2}{*}{ Statements } & \multicolumn{5}{|c|}{ Responses (N=28) } \\
\hline & $\begin{array}{c}1 \\
\text { Strongly } \\
\text { Disagree }\end{array}$ & $\begin{array}{c}2 \\
\text { Disagree }\end{array}$ & $\begin{array}{c}3 \\
\text { Neither } \\
\text { Agree or } \\
\text { Disagree }\end{array}$ & $\begin{array}{c}4 \\
\text { Agree }\end{array}$ & $\begin{array}{c}5 \\
\text { Strongly } \\
\text { Agree }\end{array}$ \\
\hline $\begin{array}{l}\text { Q1. Multilieteraciesis useful to } \\
\text { support your understanding in } \\
\text { learning writing, such as the } \\
\text { use of pictures/images or } \\
\text { videos }\end{array}$ & $0(0 \%)$ & $0(0 \%)$ & $1(3.6 \%)$ & $14(50.0 \%)$ & $13(46.4 \%)$ \\
\hline $\begin{array}{l}\text { Q2. Digital literacy is } \\
\text { significant to improve your } \\
\text { writing skills, such as making } \\
\text { outline online, google doc for } \\
\text { writing feedback, utilizing } \\
\text { online grammar tools }\end{array}$ & $0(0 \%)$ & $0(0 \%)$ & $2(7.1 \%)$ & $15(53.6 \%)$ & $11(39.3 \%)$ \\
\hline $\begin{array}{l}\text { Q3. Involving digitality is } \\
\text { effecient in the proses of }\end{array}$ & $0(0 \%)$ & $0(0 \%)$ & $2(7.1 \%)$ & $10(35.7 \%)$ & $16(57.1 \%)$ \\
\hline
\end{tabular}


Nabhan, EduLite: Journal of English Education, Literature, and Culture

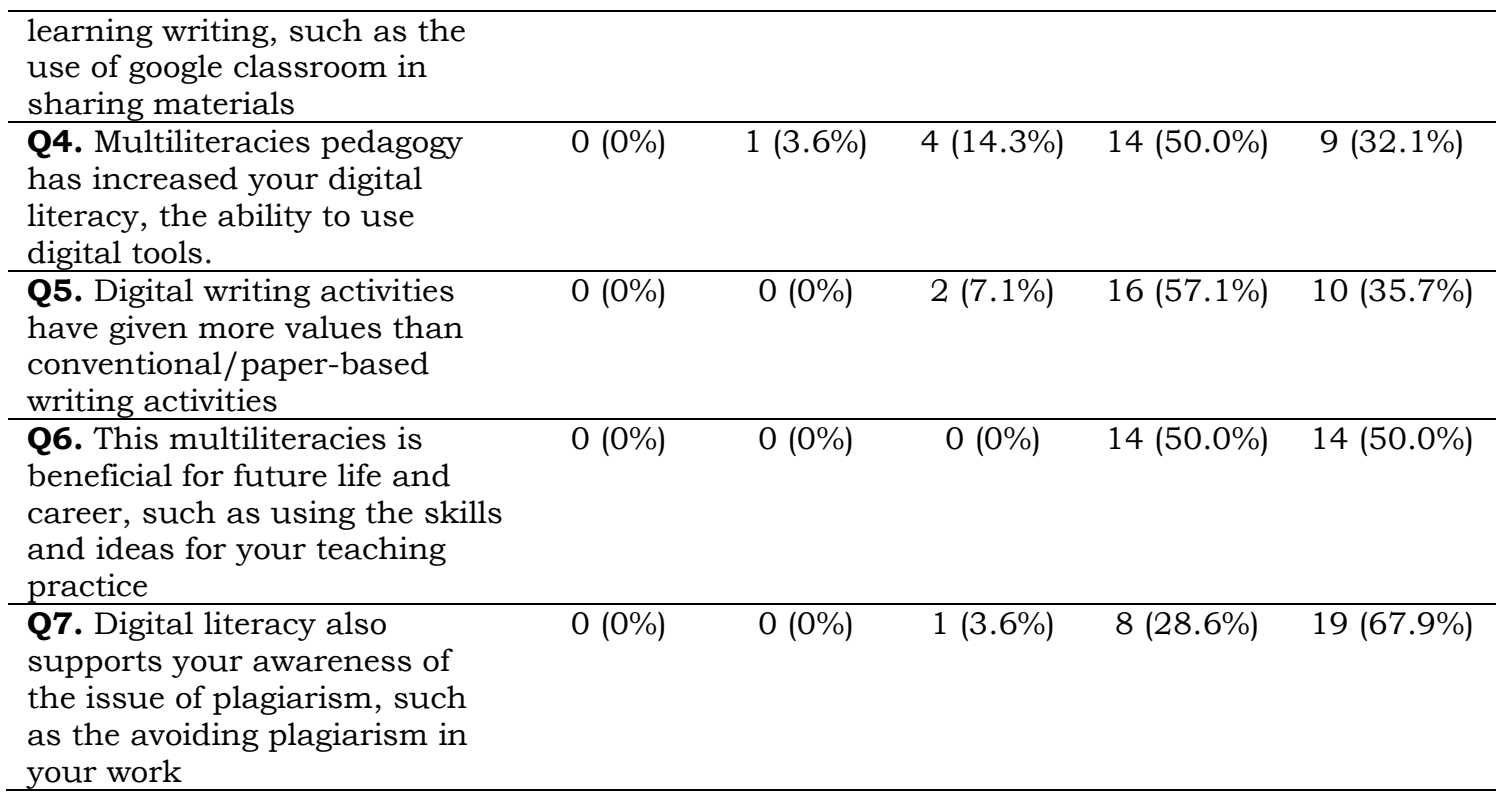

Referring to the table 2 above, in terms of PSTs' understanding in learning writing, the result indicated that respectively $50 \%$ and $46.4 \%$ of PSTs agreed and strongly agreed that multiliteracies is useful to support their understanding in learning writing. While the rest 3.6\% of PSTs neither agreed or disagreed. Also, concerning with PSTs' Writing skill improvement, most of PSTs (53.6\%) agreed, 39.3\% of PSTs strongly agreed, and only $7.1 \%$ of PSTs neither agreed or disagreed that digital literacy was significant to develop thier writing ability, such as utilizing the software/application online for making outline, giving feedback, editing, and checking grammar.Meanwhile, in connection with efficacy, the result displayed that $57.1 \%$ of PSTs strongly agreed, $35.7 \%$ of students agreed, and the rest $7.1 \%$ of PSTs neither agreed or disagreed that digital literacy engagement is proven to be efficient in the classroom. For example, when they received the materials and submited the assignment online using google classroom.

With regard to digital literacy improvement as seen in table 2, most PSTs (50.0\%) agreed, 32.1 of PSTs strongly agreed, $14.3 \%$ of PSTs neither agreed or disagreed, and only $3.6 \%$ of PSTs disagreed with the idea that multiliteracies pedagogy improved their digital literacy and capacity to utilize digital tools. Then, related to the value of digital literacy, $57.1 \%$ dan $35.7 \%$ of PSTs respectively strongly agreed and agreed with the notion that digital writing activities gave more values than traditional way of teaching. While the rest of PSTs $(7.1 \%)$ were in neutral position. Additionally, In terms of the benefits for future life, half of PSTs (50.0\%) strongly agreed and the rest (50.0\%) agreed that multiliteracies could give benefits for future life and their professions. Finally, in line with the issue of plagiarism, most PSTs $(67.9 \%)$ strongly agreed, $28.6 \%$ of PSTs agreed, and only $3.6 \%$ of PSTs neither agreed or disagreed that digital literacy built their awareness toward plagiarism. 


\section{Reflective diaries}

Table 3. Sample reflection of the activities from PSTs

\begin{tabular}{|c|c|c|}
\hline No & Process Writing & Extracts of Reflection \\
\hline 1 & Pre writing & $\begin{array}{l}\text { "I think activities involving modalities and digitality by } \\
\text { presenting materials using projector, sharing materials using } \\
\text { google classroom, pictures of bullying and pollution very } \\
\text { helpful in learning writing" (RD: PST 6) } \\
\text { "These activities are very helpful to understand what the } \\
\text { lecturer explains. It is easier and more practical" (RD: PST 4) }\end{array}$ \\
\hline 2 & $\begin{array}{l}\text { Planning and } \\
\text { Organizing }\end{array}$ & $\begin{array}{l}\text { "Using mind map online is easier than writing on paper, not } \\
\text { wasting time, send it directly to WhattsApp web" (RD: PST 3) } \\
\text { "In my opinion, it is harder than making mind map using } \\
\text { paper because we have to be careful in saving the document. It } \\
\text { takes a long time when we losethe document suddenly because } \\
\text { we have to make it again" (RD: PST 7) } \\
\text { "It needs internet connection. If the connection gets trouble, we } \\
\text { will get difficulties" (RD: PST 17) }\end{array}$ \\
\hline 3 & Drafting & $\begin{array}{l}\text { "I think it is more simple than writing in paper, because when } \\
\text { there is something wrong we just need to delete in } \\
\text { computer...."( RD: PST 2) } \\
\text { "I really like the activity because it makes writing becoming fun } \\
\text { activity. It also can be done directly with mobile phone or } \\
\text { laptop without spending much time to write manually" (RD: } \\
\text { PST 12) }\end{array}$ \\
\hline 4 & Reflection & $\begin{array}{l}\text { "... review it again at home online..." (RD: PST 14) } \\
\text { "I agree with it because it saves the time. In the campus, we } \\
\text { just focus on the materials and we practice and do the } \\
\text { assignment at home" (RD: PST 21) }\end{array}$ \\
\hline 5 & Peer/Tutor Review & $\begin{array}{l}\text { "Using google docs for correction is faster than using paper. } \\
\text { Lecturer can give the comment and send it directly to the } \\
\text { students" (RD: PST 8) } \\
\text { "In my opinion, using Google Docs in reviewing is more } \\
\text { practical because we can sent and open the reply of revision } \\
\text { from the lecturer fast. We learn easier than the conventional } \\
\text { manner" (RD: PST 20) }\end{array}$ \\
\hline 6 & Revision & $\begin{array}{l}\text { "By revision on screen, it is not wasting time for students to } \\
\text { make correction"(RD: PST 26) } \\
\text { "Revision process is so easy because we can revise it anywhere } \\
\text { and anytime when we bring our mobile phone" (RD: PST 2) }\end{array}$ \\
\hline 7 & $\begin{array}{l}\text { Editing and } \\
\text { Proofreading }\end{array}$ & $\begin{array}{l}\text { "Checking plagiarim online is helpful to minimize plagiarism" } \\
\text { (RD: PST 23) } \\
\text { "It is good because we can know if our assignment is pure or } \\
\text { just copied from the Internet" (RD: PST 9) }\end{array}$ \\
\hline 8 & Publishing & $\begin{array}{l}\text { "Becausewe have to design multimedia in our presentation, we } \\
\text { have to learn how to operate the application" (RD: PST 19) } \\
\text { "We learn some thing new that is not just writing but also } \\
\text { presenting our writing in other form like poster or publishing } \\
\text { in weblog. It can develop our creativity" (RD: PST 28) }\end{array}$ \\
\hline
\end{tabular}

\section{PSTs' focus group discussion and observations}

From the questions regarding the benefits of digitality and multimodality, PSTs indicated that they learnt other skills instead of just writing. "Besides learning the subject, I also learn about technology that is used in teaching and learning Writing," one PST stated. In addition, PSTs enjoyed the learning process.

I like to use technology in my every day activities. When the teacher asked us to discuss and make mind map of the essay using online application in group, I enjoyed the activities very much, even though I am not familiar 
Nabhan, EduLite: Journal of English Education, Literature, and Culture

with the application. I could learn it fast and do the activities well. (FGD, PST 3).

More over, one of PSTalso got inspired from the use of the framework, "This activities really inspire me to do the same thing when I become a teacher. I will use the ideato teach to my students" (FGD, PST 1). Despite those benefits, based on the observation during, it is also found that some PSTs got difficulty in using the application. Some PSTs asked some problems they encountered when they were operating the digital tools.

\section{Discussion}

\section{Understanding in learning writing}

Findings of the study reveal that writing activities involving multiliteracies such as using pictures/images and videos helped improve PSTs' understanding toward the materials. Further, in the stage of pre writing focusing on brainstorming, PSTs were provided with some pictures and videos related to the topic of writing. This is to say, PSTs agreed that presenting materials with the combination of pictures or videos have made their meaning making process much easier, and thus they could develop their idea well.According to one of PSTs written in the reflective diaries, "these activities are very helpful to understand what the lecturer explains. It is easier and more practical" (RD: PST 4). A study by Álvarez (2016) recomended to integrate multimodal perspective in teaching language through optimalizing all potential elements in communication to create the meaning, thus learners need to focus on understanding how to intepret the multimodal texts. However, research conducted by Pavio and Mayer (as cited in Álvarez, 2016) argued that despite the fact that combination of communication modes improve learners' understanding, those combinations obstruct comprehension.

\section{Efficacy and writing skill improvement}

PSTs' perception regarding writing skills improvement is also highlighted. Almost all PSTs were in the same mind that that multilitecies promoted their ability in writing. During the process writing activities such as making mind map to organise their ideas prior to writing outline, PSTs were asked to create mind map using online application. Online application provides some tools that are easy to use. Through group discussion, all ideas from the member in the group were gathered and organized in an online application. This kind of activity was also proposed by Sánchez (2017). Her study examined the digital concept map to help learners develop metacognitive writing skills and their empowerment by providing leaners with digital tools to organize their thoughts. This approach allowed learners to use multimodality that the online resourses have. Likewise, PSTs agreed that involving digitality was efficient in the process of writing activities and the activities also promote PSTs' interest and motivation. During the process writing, some digital application such as Google Classroom and Google Docs were utilized in teaching and learning activities. One of PST commented, "I really like the activity because it makes writing becoming fun activity. It also can be done directly with mobile phone or laptop without spending much time to write manually" (RD: PST 12). 


\section{Promoting digital literacy}

With regard to digital literacy improvement trough multiliteracies pedagogy in writing process, most of PSTs claimed that their ability to utilize the digital tools enhance since the design tasks required PSTs to create multimodal texts related to the topic given, hence they had to learn and practice all the time using that digital applications. The frame develops digital writing spaces in which the types of composition projects vary covering posters, vlogs-youtube, weblogs, multimedia, and other interactive platforms. This is to say that it demonstrates new ways of writing competency, including composing with audio visual and new technologies. Further, it also promotes electronic submission of assignment. This point is relevant with the statement made by one of PSTs, "because we have to design multimedia in our presentation, we have to learn how to operate the application" (RD: PST 19). The other PST added "We learn some thing new that is not just writing but also presenting our writing in other forms like poster or publishing in weblog. It can develop our creativity" (RD: PST 28). This benefit is in line with the study conducted by Yeh (2018) indicating that learners perceived advantages related to the process of multimodal video creation. In his study, PSTs were taught to use some digital devices in their learning experinces. Thus, such activities promoted their multiliteracies to defferent degrees. In addition, this study indicates that digitality in the classroom also provides more benefits than traditional approach. The result of the study regarding the benefits of multiliteracies supports the arguments that working with multimodal allows learners to be more independent, motivated, and critical (Ganapathy, 2016; Rajendram, 2015; Smith, 2014).

\section{Benefits for future life}

In this study, all the PSTs were positive with the thought that multiliteracies is beneficial for their future life. This is to say that it has the real life connection. Since the partcipants of the study were the pre-service teachers in which they will implement what they have learnt during their study for their future professinal career, the designed framework provides them with multiliteracies, the ability of pedagogy or teaching skills, and the source of knowledge that inspire them when they become a teacher in the future. This is supported by the statement of PST, "these activities really inspire me to do the same thing when I become a teacher. I will use the idea to teach my students" (FGD, PST 1). Enacting the framework in writing activities gives opportunities to embrace the multiple modes of meaning making and digital technology in creative ways, and therefore PSTs are expected to be able to communicate succesfully in the digital communication.

\section{Awareness of plagiarism}

The study shows that multiliteracies has contributed to decrease the chance of plagiarism and increase the authentic writing. In view of the fact that the availability of source of materials is provided in the Internet, and students can easily access them, this leads to the act of plagiarism. However, in the proposed framework, PSTs were educated to use the Internet wisely and further utilize them to check their writing online. Similarly, Álvarez (2016) suggested, "it is necessary that students be introduced to the rules fair use 
Nabhan, EduLite: Journal of English Education, Literature, and Culture

and proper attribution of online materials" (p. 113). Several websites are available to provide online application for plagiarism checker such as Smallseotools website. Introducing them with the online plagiarism checker raises their awareness to avoid plagiarism. One of the PSTs commented, "checking plagiarim online is helpful to minimize plagiarism" (RD: PST 23). Additionally, other PST supported, "it is good because we can know if our assignment is pure or just copied from the Internet" (RD: PST 9).

\section{Challenges}

Inspite of the fact that implementing the framework provides several benefits in PSTs' writing skill and literacy, the study also reveals several challenges. The challenges can be identified in terms of time and effort, learning online facilites, and PSTs' qualification. The proposed framework involves digital devices instead of tranditional way of teaching and learning, therefore it may need time and effort. One of PST wrote in the reflective diaries, "in my opinion, it is harder than making mind map using paper because we have to be careful in saving the document. It takes a long time when we lose the document suddenly because we have to make it again" (RD: PST 17). Relating to online facilties, since the application requires internet connection, the Internet becomes very significant. One of PSTs commented, "it needs internet connection. If the connection gets trouble, we will get difficulties" (RD: PST 17). In addition to this challenges, PSTs' ability in operating the digital tools matters in implementing multiliteracise. Those challenges are in line with the study conducted by Bouziane (2013). He argued that the hardware, software, knowledge, and internet connectivity contribute to the barriers in the language classes.

\section{CONCLUSION}

This research was designed to investigate the enactment of multiliteracies and process writing approach framework as well as PSTs' reflection on their experiences. The findings provide the empirical evidence that the proposed framework provides PSTs with the engaging and motivating process writing along with practical activities through some stages of pre-writing, planning, organizing, drafting, reflection, peer/tutor review, revision, editing, proofreading, and publishing integrated with the multiple modes of linguistics, audio, visual, gestural, spatial, and digital. Seen from PSTs' reflection, the study affirms that the framework provides several benefits in terms of PSTs' comprehensionon the teaching materials, writing skill enhancement, and the awareness toward the issue of plagiarism. In addition, the activities also provide PSTs with the chance to engage with the learning technology and thus promote the students' digital literacy. However, the framework also offers some challenges of the PSTs' effort, qualification, and online learning facilities. In sort, the study reflects the experiences of teaching and learning that are multimodal to develop the PSTs' literacy skills that are needed in today's world.

\section{Limitations}

In spite of the fact that the study provides some information, there are several limitations. One of the majors limitation is that this study did not discuss 
about the assessment of the framework. The researcher focused more on the PSTs' perception regarding the implementation in the classroom. In addition to that,s ince the application to check PSTs' grammar was free and available online, that software did not work as being expected, and hence the result of the grammatical checking was still far from being perfect. Therefore, this was challenging for the PSTs to check their work independently. A future study is necessary to explore the assessment of multiliteracies in teaching writing.

\section{Implications}

The findings of the study provide information on the implementation of multiliteracies and process writing approach framework and its reflection. The implication of the study might be beneficials for the literacy education in EFL context for the university level. In teaching language, embracing multimodality may help the learners to achieve the target of language skill as well as the literacy skills, and this is effective when it is integrated into the syllabus or lesson plan.

\section{REFERENCES}

Ajayi, L. (2012). How teachers deploy multimodal textbooks to enhance English language learning. TESOL Journal, 6(1), 16-35.

Alodwan, T. A. A., \& Ibnian, S. S. K. (2014). The effect of using the process approach to writing on developing university students' essay writing skills in EFL. Review of Arts and Humanities, 3(2), 139-155.

Álvarez, J. (2016). Meaning making and communication in the multimodal age $\square$ : ideas for language teachers. Colombian Applied Linguistics, 18(1), 98-115. https://doi.org/http://dx.doi.org/10.14483/calj.v18n1.8403 Abstract

Bouziane, A. (2013). ICT integration in language teaching: Some challenges. The Tunisian English Language Teaching Forum, 7, 13-27. Retrieved from https://issuu.com/tarakbr/docs/forum_issue7

Cloonan, A. (2010). Technologies in literacy learning: A case study. E-Learning and Digital Media, 7(3), 248-257. https://doi.org/10.2304/elea.2010.7.3.248

Coffin, Caroline; Curry, Mary jane; Goodman, Sharon; Hewings, Ann; Lillis Theresa M.; Swann, J. (2003). Teaching academic writing in European higher education. Retrieved from http:/ / public.eblib.com/choice/ publicfullrecord.aspx?p=197828

Cope, B., \& Kalantzis, M. (2009). "Multiliteracies ": New literacies, new learning. Pedagogies: An International Journal, 4(3), 164-195. https://doi.org/10.1080/15544800903076044

Ganapathy, M. (2016). The effects of using multimodal approaches in meaning-making of 21 st century literacy texts among ESL students in a private school in Malaysia. Advances in Language and Literary Studies, 7(2), 143-155. https://doi.org/10.7575/aiac.alls.v.7n.2p.143

Greco, D. C. (2015). Multiliteracies : Bringing multimodality into schools (State 
Nabhan, EduLite: Journal of English Education, Literature, and Culture

University of New York). Retrieved from http://digitalcommons.brockport.edu/ehd_theses /630\%0A

Harmer, J. (2004). How to teach writing. England: Pearson Education Limited.

Hasan, K., \& Akhand, M. M. (2010). Approaches to writing in EFL/ESL context: Balancing product and process in writing class at tertiary level. Journal of NELTA, 15(1-2), 77-88.

Mackey, A. (2005). Second language reseacrh: Methodology and design. New Jersey: Lawrence Erlbaum Associates.

Nabhan, S. (2016). The process approach to improve students' writing ability in English education department University of PGRI Adi Buana Surabaya. Jembatan Merah, 13(June), 1-15.

NLG. (1996). A pedagogy of multiliteracies : Designing social futures. Harvard Educational Review, 66(1), 60-92.

Nordin, S. M., \& Mohammad, N. (2006). The best of two approaches: Process/Genre based approach to teaching writing. The English Teacher, $X X X V, 75-85$. Retrieved from http://www.melta.org.my/ET/2006/2006_6.pdf

Rajendram, S. (2015). Potentials of the multiliteracies pedagogy for teaching English language learners (ELLs ): A review of the literature. Critical Intersection in Education: An OISE/UT Students' Journal, 3, 1-18.

Sánchez, A. C. (2017). A multimodal concept map approach to L2 writing: Emancipating non-native English students. International Journal of Languages, Literature and Linguistics, 3(4), 234-237. https://doi.org/10.18178/ij111.2017.3.4.139

Sewell, W. C., \& Denton, S. (2011). Multimodal literacies in the secondary English classroom. English Journal, 100(5), 61-65. Retrieved from http://www.jstor.org/stable/23047804

Smith, A. M. (2014). Multimodal literacy in the English / language arts classroom: Meeting standards and remaining relevant in the 21 st century (The College at Brockport: State University of New York). Retrieved from http://digitalcommons.brockport.edu/ehd_theses

Tangkiengsirisin, S. (2006). Approaches to teaching second language writing. Language Institute Journal, 3, 1-26.

Vagias, W. (2006). Likert-type scale response anchors. Clemson International Institute for Tourism \& Research Development, Department of Parks, Recreation and Tourism Managament. https://doi.org/10.1525/auk.2008.125.1.225

Walsh, M. (2010). Multimodal literacy: What does it mean for classroom practice? Australian Journal of Language and Literacy, 33(3), 211-239.

Warner, C., Richardson, D., \& Lange, K. (2019). Realizing multiple literacies through game-enhanced pedagogies : Designing learning across discourse levels. Journal of Gaming \& Virtual Worlds, 11(1), 8-29. https://doi.org/10.1386/jgvw.11.1.9 
EduLite Journal of English Education, Literature, and Culture Vol.4, No.2, August 2019, pp. 156-170

E-ISSN: 2528-4479, P-ISSN: 2477-5304 http://jurnal.unissula.ac.id/index.php/edulite DOI: http://dx.doi.org/10.30659/e.4.2.156-170

Yeh, H.-C. (2018). Exploring the perceived benefits of the process of multimodal video making in developing multiliteracies. Language Learning and Technology, 22(2), 28-37. https://doi.org/10.125/44642 